た。 また，唾液腺体積，身長，BMIによる喠液分泌速度の標準化により，唾液分泌速度の有意な男女差を無くすこと が出来た。これらの結果から，唾液分泌速度の男女差が，男女の体格の違いに基づいた唾液腺体積の違いによるもの であることが示唆された。

\title{
Gender difference in unstimulated whole saliva flow rate and salivary gland sizes
}

Hiroko Inoue (Division of Periodontology, Kyushu Dental College)

In this study, we investigated the relationships among unstimulated whole saliva flow rate (UWSFR) , gland sizes and body sizes. The saliva was collected in 50 healthy young adults, and the flow rate was measured. Heights and weights were measured, and BMI were calculated. The salivary gland sizes were measured by using a MRI technique. Parotid and submandibular gland sizes and flow rates in females were significantly smaller than those in males, as were also the weights, heights and BMI. In both males and females, there were significant positive correlations between gland sizes and the flow rates, weights and BMI. These results suggest that the lower UWSFR in females as compared to that in males are due to the smaller gland sizes due to the smaller body sizes.

\section{2.ガラニンはラットスライス標本において脳弓下器官ニューロンを抑制する}

甲斐 絢（九歯大·侵襲制御）

ガラニンは摂食促進, 疼痛の発生, 記憶抑制に関与する摂食促進ぺプチドとして知られている.ラット中枢にガラ ニンを投与すると飲水を抑制することが最近報告された，吅渴中枢のひとつである脳弓下器官は，アンジオテンシン II 投与により興奮し, 飲水を促進させることから, ガラニンによる飲水行動の抑制は, 脳弓下器官ニューロンの神経 活動を抑制して引き起こされた可能性が示唆された。本研究ではラット脳弓下器官スライス標本を用い，分子生物学 的, 電気生理学的, 解剖学的手法によりガラニンの影響を調べた結果, 神経調節性に放出されるガラニンが脳弓下器 官ニューロンの GalR1 を介して神経活動を抑制することが，飲水行動を抑制するメカニズムの1つと考えられた.

\section{Galanin inhibits neural activity in the subfornical organ in rat slice preparation}

Aya Kai (Division of Dental Anesthesiology, Kyushu Dental College)

The activation of the subfornical organ (SFO), a circumventricular organ, induces water intake and vasopressin release. Since central administration of galanin (GAL) suppresses water intake and vasopressin release, GAL may inhibit the neural activity of SFO neurons. In the present study, we investigated effects of GAL on the SFO using molecular biological, electrophysiological and anatomical techniques. Many GAL-sensitive SFO neurons showed excitatory responses to angiotensin II (ANGII). These results suggest that the SFO has neural inputs involving GAL. The response to GAL is inhibitory, mediated at least in part by GalR1, and provides a plausible explanation for the opposite effects of ANGII and GAL seen in vivo on water intake and vasopressin release.

3. Actinobacillus actinomycetemcomitans に感染したマクロファージのアポトーシスにおけるカスペース -3 を通じたカスペース $-8,-9$ の関与

原田＼cjkstart依美（九歯大·歯周病学）

近年, 歯周病原菌によって発症する全身疾患が特に注目され, 国内外の研究者から数多くの研究成果が報告されて いる．なかであ若年性歯周炎や難治性歯周炎の原因菌として考えられている Actinobacillus actinomycetemcomitans は，これらの疾患のみならず，全身疾患を引き起こすことが知られている.

そこで本研究では，A. actinomycetemcomitansに感染したマクロファージのアポトーシス誘導の過程における caspase-8 および caspase-9 の関与について検討した.

マウスマクロファージであるJ774.1にA. actinomycetemcomitans $\mathrm{Y} 4$ 株を細菌/細胞比 5000:1で感染させた。ま 
ず, J774.1 をaspase-3, -8, -9 阻害剤存在下で A. actinomycetemcomitans と培養し, アポトーシス細胞の出現をフ ローサイトメーターで検討した。 また感染させた J774.1 細胞に caspase-9 阻害剤を添加し, caspase-3 の活性化につ いて検討した. 興味深いことに, A. actinomycetemcomitans 感染マクロファージでは, caspase-8 および caspase-9 を介した経路で別々に caspase-3 が活性化されることが明らかとなった. さらに A. actinomycetemcomitans 感染マ クロファージ内で caspase-8 および caspase-9 で活性化された caspase-3により細胞内タンパクである poly（ADPribose) polymerase（PARP）が分解されることが明らかとなった.この結果から，A. actinomycetemcomitans 感 染マクロファージのアポトーシス誘導時特有の形態変化には, caspase-8, caspase-9 および caspase-3 の活性化が 関与していることが強く示唆された。

Involvement of caspase- 8 and $\mathbf{- 9}$ in apoptosis in macrophages infected with Actinobacillus actinomycetemcomitans through caspase- 3 activation

Emi Harada (Division of Periodontology, Kyushu Dental College)

Actinobacillus actinomycetemcomitans is a facultative intracellular bacterium capable of inducing apoptosis in murine macrophages. In this study, we investigated the caspase cascade in apoptotic cell death of $A$. actinomycetemcomitans-infected macrophages. Flowcytometric analysis revealed that inhibitors of caspase- $3,-8$ and -9 significantly inhibited the apoptotic cell death of infected macrophages. We obtained evidence that infection with $A$. actinomycetemcomitans induced the activation of the caspase -8 and -9 and the executioner caspase- 3 by immunoblot analysis. The activation of caspases induced the cleavage of poly (ADP-ribose) polymerase (PARP). These cleavages were observed within 12 to $18 \mathrm{~h}$ after the infection with $A$. actinomycetemcomitans. The PARP cleavage resulting from activation of the apoptotic pathways was prevented by the caspase-3, -8 and -9 inhibitors. These findings indicate that the pathway of $A$. actinomycetemcomitans-induced apoptosis involves the activation of caspases $-3,-8$ and -9 , and that the activation of caspase- 3 plays an important role in the cleavage of PARP during apoptosis in A. actinomycetemcomitans-infected macrophages.

\section{CDT が誘導するアポトーシスにおける核膜タンパクの解析}

河村 太郎（九歯大・フロンティア）

Actinobacillus actinomycetemcomitans は歯周病の原因と考えられているロ腔内細菌で, 細胞死を引き起こす cytolethal distending toxin (CDT) を産生する. 今回, 我々は遺伝子組み換え型 CDT をヒト単球細胞 U937 細胞 に作用させ，アポトーシス発現メカニズムを分子生物学的な手法を用いて解析した. CDTを作用させた U937 細胞は 18 時間後には $\mathrm{G}_{2} / \mathrm{M}$ 期での細胞周期停止が観察され，24 時間後には細胞膨張と核濃縮が引き起こされた. 24 時間後, 核膜成分である lamin A/C の開裂も観察されたが，この開裂は caspase-6 を阻害すると著しく減弱され， caspase-9を阻害すると部分的に減弱された。しかし, caspase-3/7/8 阻害しても変化はみられなかった。 以上の ことから, CDTが誘導するヒト単球細胞のアポトーシスには, caspase の活性化により誘導されるとともにアポ トーシス特有の lamin A/C 開裂にあ深く関与していることが示唆された.

\section{Involvement of Lamin $\mathrm{A} / \mathrm{C}$ in Apoptosis of Human Monocytic Cells Induced by Actinobacillus actinomycetemcomitans Cytolethal Distending Toxin}

Taro Kawamura (Division of Connnunity Oral Health Science, Kyushu Dental College)

Actinobacillus actinomycetemcomitans, an oral bacterium implicated in the etiology of periodontal diseases, produces cytolethal distending toxin (CDT) that induces $\mathrm{G}_{2} / \mathrm{M}$ cell cycle arrest followed by cell death. We examined cell death induced by purified recombinant CDT in human monocytic U937 cells, and analysed the molecular mechanisms involved in the apoptotic pathway. Flow cytometry revealed that $\mathrm{U} 937$ cells treated with CDT were arrested in the $\mathrm{G}_{2} / \mathrm{M}$ phase of the cell cycle after $18 \mathrm{~h}$. 